\title{
A new Quaternary and Neogene lithostratigraphical framework for Great Britain and the Isle of Man
}

\author{
A A McMillan ${ }^{1}$ and $\mathrm{J}$ W Merritt ${ }^{2}$
}

${ }^{1}$ Formerly British Geological Survey, Murchison House, West Mains Road, Edinburgh EH9 3LA; ${ }^{2}$ British Geological Survey, Murchison House, West Mains Road, Edinburgh EH9 3LA Corresponding author: J W Merritt,jwm@bgs.ac.uk.01316671000.

Keywords: Lithostratigraphy; Quaternary; Superficial deposits

\begin{abstract}
This paper provides a synthesis of the recently published BGS report presenting a new Lithostratigraphical Framework of Quaternary and Neogene deposits for Great Britain and the Isle of Man (McMillan et al., 2011). Available as a download from the BGS website, the report sets out a hierarchy of lithostratigraphic units for superficial deposits providing summary descriptions of lithological characteristics, boundaries, ranges in thickness, type sections and known geographical distribution. This paper describes the requirement, rationale and development of the onshore scheme, and discusses the philosophy behind its creation. It discusses unique problems in stratigraphy presented by superficial deposits and introduces a new lithostratigraphical subdivision of tills laid down during the last regional glaciation (Late Devensian/Weichselian/Wisconsin).
\end{abstract}

\section{Introduction}

The publication earlier this year (McMillan et al., 2011) of the Lithostratigraphical Framework of Quaternary and Neogene deposits for Great Britain (onshore) is the culmination of a research project initiated by the British Geological Survey in 1998 and taken on under the direction of the BGS Stratigraphy Committee. Recognising the need to provide a workable framework to aid future Quaternary mapping, modelling and research, and a stratigraphical scheme capable of use in a wide variety of applications (see Foster et al., 1999), the BGS tasked a group of mapping geologists to develop a hierarchy that should utilise the full range of units from supergroup to bed. It needed to conform as far as possible with international stratigraphical principles for lithostratigraphical classification as provided by the International Union of Geosciences (IUGS) (Hedberg, 1976; Salvador, 1994), and the national/regional guidance offered by the North American Commission on Stratigraphical Nomenclature (NACSN) (1983, 2005), Whittaker et al. (1991) and Rawson, et al. (2002). 
The project commenced at the time that the Geological Society of London published a Revised Correlation of Quaternary deposits in the British Isles (edited by D Q Bowen, 1999), the first edition having been published some 26 years earlier (Mitchell et al., 1973). Both of these publications, together with the Quaternary volumes of the Geological Conservation Review Series (e.g. Gordon and Sutherland, 1993; Bridgland, 1994; Huddart and Glasser, 2002) proved to be invaluable sources of information and citation, and several contributors to the Bowen (1999) edition contributed to and commented on the BGS framework. Stratigraphical charts correlating the principal units of the onshore framework with the recently published BGS offshore Quaternary lithostratigraphical framework (Stoker et al., 2011) are in preparation (Stoker et al., 2012a,b).

\section{Development of the Framework}

Bowen (1999) defined some 1400 units at formation, member and bed levels. However, the formations defined therein generally embrace sequences of deposits of diverse lithology and depositional environment. The members and beds of these formations generally represent the mappable units, not the formations. This is particularly in case for Scotland. Many of the formations of Bowen (1999) are valuable, representative, regional stratigraphical successions, which arguably should have been given group or sub-group status. The BGS project team consequently recognised the utility of expanding the hierarchy to include groups, since grouping of formations is desirable, particularly to aid regional mapping (Salvador, 1994) and interpretation by non-geologists.

The new groups have been established mainly on depositional environment and gross lithological characteristics. This approach was suggested by Willman and Frye (1970) in establishing a Pleistocene stratigraphical framework of Illinois. Widely varying lithological characteristics, for example of glacigenic sediments derived from many sources, is reflected in some of the groups, the bases of which are defined by basin-wide unconformities. Early thoughts on a possible hierarchy were published by McMillan and Hamblin (2000), and refined in a subsequent 'overview' report (McMillan et al., 2005), the key points of which were discussed at the TNO International Workshop on Integrated Land-Sea Lithostratigraphic Correlation in Utrecht, The Netherlands, in April 2003 (McMillan, 2005). In parallel, a novel chronostratigraphical classification applicable to the UK, and based upon an embracing forcing-event stratigraphy, was developed by Rose (2003, 2010). Elsewhere, particularly applicable in glaciated terrains (e.g. in Finland), an allostratigraphical scheme has been adopted (Räsänen et al., 2009) in which formations are defined by unconformable 
boundaries. A similar approach based mainly on seismo-stratigraphy has been utilised for the Quaternary deposits lying offshore the UK (Stoker et al., 2011).

Subgroups have been introduced within some of the groups. These are defined on lithological characteristics and geographical extent of component formations. Rawson et al. (2002) acknowledged that the term subgroup is not in the formal hierarchy, but has been usefully employed for subdividing certain groups, for example the Chalk. However, as Rawson et al. (2002) note, definition of a group and subgroup may be contentious. For reasons such as this it is necessary to consider the Quaternary as a 'special case'(see discussion below) .

For the BGS framework it was determined that although the groups should have a broad genetic background they should be defined by the lithological characteristics of the principal component formations, many of which were already defined (see Bowen, 1999); others are modified from earlier definitions or are completely new. The formation is generally agreed to be the primary mappable unit (Rawson et al., 2002). Hitherto, no formal Quaternary lithostratigraphy has been applied over much of the UK and both national and regional correlation has proved difficult. Superficial (formerly Drift) deposits are commonly lithologically variable and spatially discontinuous. Despite a legacy of over 175 years of mapping at a range of scales, Quaternary deposits are variably recorded in both academic and geological survey publications and maps.

Traditionally, lithostratigraphical studies were confined to parts of the UK near or beyond the limits of glaciation where the best-preserved Quaternary record could be established. Thus a stratigraphical framework was first established for eastern and central England, notably East Anglia and the Midlands, and for the valleys of major river systems (see Mitchell et al., 1973). Elsewhere, geological survey mapping employed a practical 'morpho-lithogenetic' classification which had evolved since the 19th century into the currently recommended standard (McMillan and Powell, 1999; BGS, 2012). Morpho-lithogenetic units are locally mappable sediment-landform assemblages of strata that are considered without regard to time (Schenck and Muller, 1941; Salvador, 1994). In recent decades, modern surveys of superficial deposits, locally with good quality sub-surface records, and new dating techniques, have enabled formal lithostratigraphies to be developed elsewhere in the UK, notably north-west England (Merritt and Auton, 2000), west-central Scotland (Browne and McMillan, 1989; Finlayson et al., 2011) and north-east Scotland (Merritt et al., 2003). The rationale for establishing the defining criteria of the framework with particular reference to glacigenic and catchment deposits is discussed in more detail later in this paper. 


\section{Groups and subgroups}

The framework of McMillan et al. (2011) establishes the Great Britain Superficial Deposits Supergroup within which seven named groups are defined. The spatial relationships and age range of the groups is shown in Figure 1, whereas the characteristics, age and distribution of the groups are summarised in Table 1. Of these, the Crag Group (after Reid, 1890, Funnell and West 1977, Arthurton et al., 1994) and the British Coastal Deposits Group (McMillan et al., 2005), comprise marine and coastal deposits. The Dunwich Group (after Rose et al., 2002, McMillan et al., 2005) and the Britannia Catchments Group (McMillan et al., 2005) comprise predominantly fluvial deposits. A Residual Deposits Group (McMillan et al., 2005) is established for mainly remanié deposits and other units which have undergone dissolution and disturbance. Two groups are assigned for glacigenic deposits, namely the Albion Glacigenic Group and the Caledonia Glacigenic Group (McMillan et al., 2005). The former group includes the Older Drift of previous classifications, whereas the later equates with the Newer Drift (Wright, 1937).

Subgroups have been introduced within some of the groups, defined on lithological characteristics and geographical extent of component formations. Two subgroups of the Dunwich Group have been defined, namely the Bytham Catchments Subgroup (after Lewis, 1993; Rose 1994) and the Kesgrave Catchment Subgroup (after Whiteman and Rose, 1992) for pre-Anglian fluvial deposits of the ancestral, pre-diversionary Thames and Bytham rivers of southern Britain (Figure 2). Subgroups of the Britannia Catchments Group are defined for formations and lithogenetic units occurring within broad, present-day physiographic regions drained by major river drainage systems that have developed since Mid-Pleistocene time. The geographical boundaries of these subgroups broadly coincide with physiographic regions defined by modern 'catchment' boundaries (Figure 3). The subgroups comprise formations defined by river terrace deposit members, floodplain alluvium and associated lithogenetic units. For deposits of the two glacigenic groups lying mainly to the north of the Devensian ice-sheet limit , a series of glacigenic subgroups is established for formations and lithogenetic units of similar lithology and provenance (Figure 2). The glacigenic subgroups are defined geographically and mainly on the basis of mappable formations of till, although some of the glacigenic water-lain units associated within them may extend beyond the Devensian limit. 
The rationale for establishing the defining criteria of the framework with particular reference to glacigenic and catchment deposits is discussed in more detail later in this paper.

\section{Discussion}

\subsection{Unique problems to lithostratigraphy presented by Superficial deposits}

Quaternary deposits present a challenge to formal stratigraphical procedures, which have been developed over many years mainly for mapping and dividing the rest of the geological column (bedrock). For example, most Quaternary deposits have not been folded and tilted tectonically. Hence it is commonly not possible to establish the precise nature of contacts between units by traditional mapping and section-logging methods alone. In many cases deposits do not crop out at the surface. Hence subdivision of the Quaternary onshore is heavily dependent on borehole information and formal type sections are commonly borehole logs, not exposures that one can examine at first hand. Furthermore, bedrock units should be defined by the nature of their lower and upper contacts, generally established on the ground, whereas numerous Quaternary units have upper contacts that represent the modern land surface, or water.

In theory, allostratigraphy should perhaps be most suited for subdividing Quaternary sequences, for example, in delineating sheets of till of different ages resting on regionally widespread unconformable surfaces. An allostratigraphical unit is a mappable stratiform body of sedimentary rock that is defined and identified on the basis of its bounding discontinuities (North American Commission on Stratigraphic Nomenclature, 1983). However, this is commonly not so simple in practice onshore, where tills vary laterally in lithology and thickness, merge with one another, or where local complications pertain. The method is more applicable offshore where seismic transects are generally available, making 'sequence stratigraphy’ easier to use. Geophysical techniques have limited utility onshore, mainly due to cost and logistics. Nevertheless, allostratigraphy is used covertly in many schemes, as for example, in the classification of river terraces adopted herein, where individual terraces are mapped as members within a flight given formational status. Each terrace deposit is defined by bounding surfaces, but the units do not form a stack as in traditional stratigraphy. Relative age is generally dependent on position within the flight, with higher terraces being older than lower ones. Many other superficial deposits are in practice mapped allostatigraphically, for example, glaciofluvial deposits and moraines, because each landform-sediment package has 
been laid down sequentially during ice sheet recession. However, in these and other cases it would be cumbersome to label each item correctly using the prefix 'allo' or 'litho'.

The Quaternary succession is thin compared to most older systems, but it is highly variable in lithology. As it is generally capable of fine resolution vertically in terms of depositional environment, provenance and age, it is appropriate to use the full hierarchy of stratigraphical units available. For example, an organic bed within a thick sequence of till may be thin, but it could represent a complete interglacial or interstadial period. A gravel lag within a thick finegrained marine sequence may have formed during a specific sea-level low-stand. Formational status may be justified for a unit just a few tens of centimetres thick, especially if it can be further subdivided. It may not be practical to map out such thin units on the ground, but it is important to be able to correctly correlate them between boreholes and with the very high resolution chronostratigraphies now available in Quaternary science, such the Greenland ice core record and microtephra-stratigraphies.

It is a challenge in the Quaternary to use lithostratigraphy conventionally to map out horizontal changes in lithology. For example, in the Carboniferous there are a plethora of named units for sequences of the same age across the country. There is no problem with this because the coalfields are discrete basins bounded by major faults. Horizontal changes in lithology are equally, or more important in the Quaternary, but such division is not possible for very widespread, flat-lying deposits. A solution adopted here is to use subgroups where some boundaries are geographically defined, as for example, in using catchment divides to subdivide the catchment groups.

\subsection{Glacigenic subgroups and formations}

The glacigenic subgroups, mainly of the Caledonia Glacigenic Group (Devensian, MIS 2-5d) have been divided geographically, some by natural boundaries, such as the Great Glen, in the Scottish Highlands, but mostly on the basis of overall lithology and provenance of the constituent formations (Figure 2). Colour remains a useful parameter for general classification of a unit, but it can be misleading locally. The concept of subdivision is not new, for example, in north-east Scotland three ‘series' of glacigenic deposits have been recognised traditionally relating to distinct bodies of ice that existed in the region during past glaciations (Merritt et al., 2003) (Figure 4). Ice flowing north-eastwards along the coast of Angus and Aberdeenshire led to the deposition of the 'Red Series', which includes a variety of materials of a typically vivid reddish brown colour. Ice flowing eastwards along the Moray 
Firth impinged onto the coastal lowlands and was responsible for laying down a suite of typically dark grey, calcareous deposits assigned to the 'Blue-grey Series'. The typically sandy, yellowish brown tills laid down in the interior by ice flowing from the eastern Grampian Highlands were assigned to an 'Inland Series'. The 'Blue-grey' and 'Inland' series have been replaced in the present scheme by the 'Banffshire Coast and Caithness' and 'East Grampian’ glacigenic subgroups respectively, whereas the 'Red Series' has been replaced by the 'Mearns' and 'Logie-Buchan' glacigenic subgroups, the latter laid down by ice that nudged onshore to the north of Aberdeen at a relatively late stage in the last glaciation, introducing a unique suite of erratics and shells from offshore: all subgroups have older, Albion Glacigenic Group (pre MIS 5e) counterparts.

The glacigenic subgroup boundaries in north-east Scotland share those dividing the surficial tills of each subgroup, namely the Banchory, Hatton, Mill of Forest and Essie till formations, which generally can be mapped out to within a few tens of metres on the ground (Figure 5). Older units, including till, glaciofluvial deposits and palaeosols, may interdigitate at depth, resulting from interactions between ice masses during several glaciations (Figure 6). For example, much of Buchan was first crossed by ice during the Devensian from the Moray Firth, laying down the heterogeneous Whitehills Glacigenic Formation with its many rafts of Mesozoic strata, before East Grampian ice sheet expanded, laying down the Crovie and Banchory till formations (Merritt et al., 2003) (Figure 6). Temporal changes in flow velocity and provenance of ice during the last glaciation also resulted in multiple sequences in Caithness and around the inner Moray Firth (McMillan et al., 2011. Although the glacial history of these regions has been documented and generally accepted for over a century, the delineation of subgroups illustrated in Figure 2 helps to conceptualize and synthesize a complicated sequence of events, thus fulfilling one of the main aims of lithostratigraphy.

Other long-established, but loosely-defined, suites of offshore-associated glacigenic deposits of the last glaciation occur down both coasts of northern England, and around the north of Wales, namely the 'Irish Sea Drift' and 'North Sea Drift' (Huddart and Glasser, 2002; Stone et al., 2010). The former has been redefined as the Irish Sea Coast Glacigenic Subgroup, whereas the latter becomes the North Sea Coast Glacigenic Subgroup (Figure 2): both have older, Albion Glacigenic Group (pre MIS 5e) counterparts. These subgroups typically contain shell fragments and re-worked, cold-water marine microfossils and are largely the legacy of ice streams that flowed southwards through the two marine basins respectively, notably during relatively late stages of the last glaciation. They contain characteristically thinly 
interbedded sequences of till, sand, gravel and silt that interdigitate with glacigenic deposits derived from land-based ice, either the Pennines or the mountains of North Wales. Although these two marine-associated subgroups can be mapped out locally to within a few tens of metres, establishing their entire geographical boundaries is more difficult and contentious. As far as is practically possible at a regional scale the source of the matrix, rather than the farther-travelled erratics in the tills, has been taken into account in placing 'up-ice' boundaries. For example, the tills of the Irish Sea Glacigenic Subgroup are typically sandy and reddish brown, reflecting their derivation from Permo-Triassic strata, both directly and indirectly. A major source of the former Irish Sea ice stream was the Solway Lowlands and the Vale of Eden, and the boundary of the subgroup thereabout roughly follows the boundary of the Permo-Triassic basin (Figure 7). The interdigitation of subgroups portrayed within the Vale of Eden (Figure 2) reflects the complex glacial history of this region, where ice first flowed up the vale before the Solway branch of the Irish Sea ice stream became established and ice flow was reversed (Stone et al., 2010; Livingstone et al., 2012, in press).

The boundaries between subgroups have been established over time, generally governed by where BGS Quaternary mapping has been in progress. In regions such as north-east Scotland, the contrasting tills were first mapped out and the subgroups established subsequently. Elsewhere subgroup boundaries had to be completed using knowledge of general ice flow trajectories and glacial history from the literature, and bedrock geology. For example, the eastern boundary of the East Grampian Glacigenic Subgroup was mapped out many years before the western boundary was established, when mapping was undertaken in the upper Spey valley.

\subsection{Till subdivision}

In recent years BGS has been developing a novel Soil Parent Material Model and a Till Thematic Layer for the country, underpinned by databases of physical properties, thicknesses, colour, clast-composition, carbonate content, etc. (Entwisle and Wildman, 2010). Geographical subdivision of the tills of Great Britain is required in order to provide more information, in particular, for distinguishing coarse-grained (primarily gravel or sand), silt and clay parent materials of soils (Griffiths, et al., 2011). Subdivision is necessary because till covers about 30\% of Great Britain yet BGS maps traditionally show till simply as 'undivided', although it is known to vary considerably in lithology and composition across the country. These initiatives are driven by the requirements of soil scientists, ground engineers, hydrogeologists and others, for whom tills present particular challenges in their 
feasibility studies, site investigation design, calculations, parameterization and modelling. The maps are an addition to a set of 'GeoSure' products that enhance and develop the output of BGS digital geological maps, providing specific GIS map layers for applied geologists, such as for 'compressible' and 'collapsible' ground, 'shrink-swell', and 'running sand' (see BGS website; http://www.bgs.ac.uk/products/geosure/home.html). These initiatives have provided the impetus to complete the lithostratigraphical subdivision of surficial tills at formation and/or member level across the country, at least within the limits of the Late Devensian glaciations (Figure 5).

The systematic geographical delineation of surficial till units was undertaken in 2009 (Entwisle and Wildman, 2010). ARC GIS was used, utilizing the BGS DiGMapGB50 Superficial and DiGMapGB-625 Bedrock Geology themes draped on a hill-shaded digital elevation model generated from the NEXTMap Britain $^{\mathrm{TM}}$ dataset from Intermap Technologies Both geology themes are available as free downloads [http://www.bgs.ac.uk/downloads]. Archive BGS mapping, digital air photos and other relevant data were used, including BRITICE, a GIS database of landforms and features related to the last British Ice Sheet (Clark et al., 2004). NEXTMap enabled drawing the boundaries as objectively as possible, which were digitized at 1:50,000 scale. For practical reasons the boundaries wriggle somewhat as they have been positioned within polygons of bedrock, or Superficial deposits other than till, in order to minimise the splitting of till polygons. The exercise provided some new insights, such as the path taken by ice that flowed northwards from the upper Spey valley directly towards the Moray Firth (Figure 8), across a mountains over $500 \mathrm{~m}$ above sea level rather than flowing down the valley towards Elgin, as previously thought (Gordon and Sutherland, 1993).

Similar protocols were followed as for the earlier delineation of glacigenic subgroups, using literature review and prior knowledge of general ice flow trajectories, glacial history and simplified bedrock geology (Figure 7). As the matrices of tills are known to bear a strong relationship with underlying bedrock (Benn and Evans, 2011), many boundaries are positioned a short distance 'down ice’ of significant changes in bedrock geology, as for example between Lower Palaeozoic greywacke dominated terrain and Permo-Trias 'red beds' in the Solway lowlands. As it is important for soil scientists and hydrogeologists to be able to identify calcareous from poorly calcareous tills, some formations have been defined and delineated to closely follow underlying limestones, for example, the Greystoke Till Formation in Cumbria (Figure 5,7) and the Ruabon Till Member of the Plynlimon Glacigenic 
Formation in north-east Wales (Figure 5), which both broadly mirror outcrops of the Carboniferous Limestone Supergroup.

NEXTmap provided invaluable information, for example, in locating end-moraines across Lancashire and Cheshire in order to map boundaries of the Kirkham, Stockport and Brewood tills, and delineating the final penetration of 'North Sea' into Tees-side, which laid down the Horden Till Formation. With these examples, and most others, previously defined units were selected if at all possible, reverting where necessary to original literature sources rather than subsequent iterations. For example, the units first established by Francis (1970) have been adopted in north-east England, even though much excellent stratigraphical work in the region has been published since this paper was written. Similarly in Wales, the till formations defined by Bowen (1999) generally have been adopted and delineated for the first time. The positions of end moraines in the Welsh borders follow Lewis and Richards (2005), adjusted from new information provided by NEXTMap. For Wales, in particular, the formations and boundaries are speculative and may be adjusted following detailed mapping in the future.

\subsection{Catchment subgroups and formations}

Catchment subgroups of the Britannia Catchments Group have been divided geographically with boundaries following present day watersheds (Figure 3) and defined primarily by formations of fluvial gravels, sands and silts of the principal and tributary rivers within each catchment. Where the deposits of the catchment can be demonstrated to have formed with little or no modification by a later over-riding ice sheet or glacier, a single formation is generally considered sufficient to define the fluvial deposits (floodplain alluvium and terraces) of a river and its tributaries (e.g. the post-Devensian, Clyde Valley Formation). However, for drainage basins that have been modified by one or more ice sheets (e.g. those of the Thames, Trent and Severn) separate formations, defined by terrace deposit members with broadly unified lithostratigraphical characteristics, have been established for the deposits of the principal river valley, or parts of it, and also for the deposits of tributary valleys. In the case of the Thames, a major river system of Neogene to Quaternary age, Bridgland (2006) has argued the case for assigning formational status to individual mappable terrace deposits comprising several members including periglacial aggradation deposits (principally sands and gravels) and interglacial/interstadial organic (peat) and fossiliferous lacustrine sediments (principally sands, silts and clays). However, the BGS Framework retains member status for terrace deposits (Figure 7) with the parent formations providing the basis for regional correlation (as adopted by Gibbard, p. 45-58 in Bowen, 1999). Formations of the 'pre- 
diversionary Thames' and the Thames and its tributaries are established within subgroups of two groups. The Kesgrave Catchment Subgroup (which forms part of the Dunwich Group) includes the lithologically distinctive Colchester and Sudbury formations of the prediversionary river (pre-Anglian) (after Whiteman and Rose, 1992). The Thames Catchments Subgroup (Britannia Catchments Group) (Anglian and younger) includes formations of river terrace deposit members within the upper reaches (Upper Thames Valley Formation), and middle and lower reaches (Maidenhead Formation, modified after Gibbard’s Maidenhead and Lower Thames formations) of the main river together with other formations for deposits of major tributary valleys (e.g. the Kennet Valley Formation). Each formation includes, at member or bed level, the terrace gravels and interbeds including peat.

Commonly terrace deposits of early fluvial systems and 'buried channel' (palaeovalley) deposits are unrelated to the present day physiography. Where such deposits cannot be biostratigraphically correlated with surficial terrace deposits of present-day valleys it is recommended that they be designated as separate formations within the Britannia Catchments Group (McMillan et al., 2005).

The stratigraphical hierarchical status of organic interbeds, including peats and soils, within glacial sequences has been the subject of much debate. Often thin and inextensive, such deposits are important for terms of regional correlation. Consequently, the most significant organic units have been assigned formational status within the Britannia Catchments Group. Examples in the Grampian Highlands (for details see Merritt et al., 2003, and McMillan et al., 2011) include the Moy Burn Palaeosol (MIS 5a-d), which overlies the Suidheig Till Formation, and the Teindland Palaeosol (MIS 5e) overlying the Deanshillock Gravel Formation. Other organic units raised to formation level include the Troutbeck Palaeosol (MIS 5e or 11), under the Threlkeld Till Formation of Cumbria (after Boardman, 1991), and the Quinton Peat Formation (comprising peat, organic sand, silt and humic clay with root traces and drifted wood) (MIS 11) overlying the Nurseries Glacigenic Formation of the Birmingham area (after Horton, 1974, 1989).

In the BGS Framework it is proposed that extensive surficial peat, lacustrine and mass movement deposits (e.g. head) which have hitherto been mapped as lithogenetic units may remain as such or, if biostratigraphically well-constrained, be raised to formational status or remain as lithogenetic units within a catchments subgroup or group, if related to more than one subgroup. 


\subsection{Lithological descriptors}

Following on from the discussion above it should be clear that the new lithostratigraphical framework is designed to be relevant for applied geologists and others with limited geological knowledge wishing to make sense of the nature and distribution of an extremely varied and heterogeneous suite of deposits. It is anticipated that the framework also will be of assistance to specialist Quaternary geologists and geomorphologists who share the ambition of making their subject as accessible to others as possible. With this objective in mind it has been decided not to follow the 'recommendations' (not specific 'rules') of Hedberg (1976) and Salvador (1994), which specify that lithological descriptors best not be used. Instead the framework has formally employed lithological descriptors in most unit names, or has reintroduced them in names where they had been removed in Bowen (1999). It was concluded that considering the plethora of named units now in existence, some indication of gross lithology would generally help more than confuse. For complex, heterogeneous sequences, terms such as 'glacigenic' have been used to embrace glacial, glaciofluvial, glaciolacustrine and locally glaciomarine deposits, but it is agreed that genetic descriptors should be used sparingly. Where units of diamicton may not be tills as strictly defined, the term 'diamicton' is preferred, as for example, the Corse Diamicton Formation of the Banffshire Coast and Caithness Glacigenic Subgroup (Merritt et al., 2003).

\section{Conclusions}

The published framework for onshore Quaternary and Neogene deposits (McMillan et al., 2011) is primarily aimed at providing a rational, hierarchical lithostratigraphical scheme for geological mapping, modelling and correlation. It presents a unified framework that aims to be of assistance in a wide range of pure and applied applications. Although specifically designed for Great Britain and the Isle of Man, the scheme is capable of application elsewhere, particularly in recently glaciated terrain.

\section{Acknowledgements}

The authors thank members of the Geological Society Stratigraphy Commission and specifically the nominated external reviewers of the Framework, Professor D Q Bowen (Cardiff, University of Wales), and Professor P L Gibbard (University of Cambridge) for their constructive reviews. For the present paper the authors also acknowledge advice and input received from Dr D T Aldiss, C A Auton, Dr J N Carney, M A E Browne, S J Booth, Dr R A Ellison, D.C.Entwisle, Dr R J O Hamblin, Dr A J Humpage, Dr D J Lowe, Dr J H 
Powell, Dr M G Sumbler, Dr C N Waters and Dr D Wilson (all BGS); and Dr E R Connell (University of Aberdeen), Dr A M Hall (University of Edinburgh), Professor J Rose (Royal Holloway, University of London), Dr W A Mitchell (University of Durham), Dr G S P Thomas (University of Liverpool), Dr W Westerhoff (TNO, Utrecht) and Dr J A Zalasiewicz (University of Leicester). The authors publish with the permission of the Executive Director, British Geological Survey (National Environmental Research Council).

\section{References}

Arthurton, R.S., Booth, S.J., Morigi, A.N., Abbott, M.A.W. and Wood, C.J. 1994. Geology of the country around Great Yarmouth. Memoir of the British Geological Survey, Sheet 162 (England and Wales), pp. 138.

Benn, D.I. and Evans, D.J.A. 2011. Glaciers and glaciations. Hodder Education, pp. 802 British Geological Survey. 2012. Specifications for the preparation of 1:10 000 scale geological maps. British Geological Survey Internal Report, IR/09/012.

Boardman J. 1991. Glacial deposits of the English Lake District. In: Ehlers, J., Gibbard, P. L., and Rose, J. (Eds), Glacial deposits in Britain and Ireland. Balkema Press, Rotterdam, pp. 175-184.

Bowen, D. Q. (Ed.) 1999. A revised correlation of Quaternary deposits in the British Isles. Special Report of the Geological Society of London No.23, pp. 174.

Bridgland, D. R. 1994. The Geological Conservation Review Series 7: Quaternary of the Thames. Chapman and Hall, London.

Bridgland, D. R. 2006. The Middle and Upper Pleistocene sequence in the Lower Thames: a record of Milankovitch climatic fluctuation and early human occupation of southern Britain. Proceedings of the Geologists’ Association 117, 281-305.

Browne, M. A. E, and McMillan, A. A. 1989. Quaternary geology of the Clyde valley. British Geological Survey Research Report SA/89/1.

Clark, C.D., Evans, D.J.A., Khatwa, A., Bradwell, T., Jordan, C.J., Marsh, S.H., Mitchell,W.A. and Bateman, M.D. 2004. BRITICE: map and GIS database of landforms and features related to the last British Ice Sheet. Boreas 33, 359-375.

Entwisle, D.C. and Wildman, G. 2010. Creation of the Till Thematic Layer. British Geological Survey Internal Report IR /10/041, pp. 14.

Finlayson, A., Merritt, J. W., Browne, M. A. E., Merritt, J. E., McMillan, A. A. and Whitbread, K. 2011 Ice sheet advance, dynamics, and decay configurations: evidence from west central Scotland. Quaternary Science Reviews 29, 969-988. 
Foster, S. S. D., Morigi, A. N. and Browne, M. A. E. 1999. Quaternary geology - towards meeting user requirements. British Geological Survey, Keyworth, Nottingham, pp. 39.

Francis, E.A. 1970. In: Johnson, G.A.L. (Ed.), Geology of Durham County. Natural History Society of Northumberland, Durham and Newcastle-upon-Tyne, Newcastle, 134-152.

Funnell, B. M., and West, R. G. 1977. Preglacial Pleistocene deposits of East Anglia. In: Shotton, F.W. (Ed.), British Quaternary Studies: Recent Advances. University Press, Oxford, 247-265.

Gordon, J. E., and Sutherland, D. G. (Eds.) 1993. The Quaternary of Scotland. Geological Conservation Review Series 6. Chapman and Hall, London, pp. 695.

Griffiths, K.J., MacDonald, A.M., Robins, N.S., Merritt, J.W., Booth, S.J., Johnson, D. and McConvey, P.J. 2011. Improving the characterization of Quaternary deposits for groundwater vulnerability assessments using maps of recharge and attenuation potential. Quarterly Journal of Engineering Geology and Hydrogeology 43, 49-61.

Hedberg, H. D. 1976. International Stratigraphic Guide: A guide to stratigraphic classification, terminology, and procedure. The International Union of Geological Sciences. John Wiley and Sons, New York.

Horton, A. 1974. The sequence of Pleistocene deposits proved during the construction of the Birmingham motorways. Report of the Institute of Geological Sciences, 74/22._HMSO, London.

Horton, A. 1989. Quinton. In: Keen, D. H. (Ed.). The Pleistocene of the West Midlands: Field Guide. Quaternary Research Association. Cambridge, 69-76.

Huddart, D., and Glasser, N. F. (Eds.). 2002. Quaternary of Northern England. Geological Conservation Review Series 25. Joint Nature Conservation Committee, Peterborough, pp. 745.

Lewis, S. G. 1993. The status of the Wolstonian glaciation in the English Midlands and East Anglia. Unpublished PhD thesis, University of London.

Lewis, C.A. and Richards, A.E. (Eds.). 2005. The glaciations of Wales and adjacent areas. Logaston Press, Logaston, Herefordshire.

Livingstone, S.J., Evans, D.J.A., O’Cofaigh, C., Davies, B.J., Merritt, J.W., Huddart, D., Mitchell, W.A., Roberts, D.H. and Yorke, L. 2012 in press. Glaciodynamics of the central sector of the last British-Irish Ice Sheet in Northern England. Earth-Science Reviews.

McMillan, A. A. 2005. A provisional Quaternary and Neogene lithostratigraphical framework for Great Britain. Netherlands Journal of Geosciences 84, 87-107.

McMillan, A. A., and Powell, J. H. 1999. British Geological Survey Rock Classification Scheme: the classification of artificial (man-made) ground and natural superficial deposits: 
applications to geological maps and datasets in the UK. British Geological Survey Research Report RR/99/4.

McMillan A. A., and Hamblin, R. J. O., 2000. A mapping-related lithostratigraphical framework for the Quaternary of the UK. Quaternary Newsletter 92, 21-34.

McMillan, A. A., Hamblin, R. J. O, and Merritt, J. W. 2005. An overview of the lithostratigraphical framework for the Quaternary and Neogene deposits of Great Britain (onshore). British Geological Survey Research Report RR/04/04.

McMillan, A. A., Hamblin, R. J. O and Merritt, J. W. 2011. A lithostratigraphical framework for onshore Quaternary and Neogene (Tertiary) superficial deposits of Great Britain and the Isle of Man. British Geological Survey Research Report RR/10/03. http://www.bgs.ac.uk/downloads/start.cfm?id=2041

Merritt, J. W., and Auton, C. A. 2000. An outline of the lithostratigraphy and depositional history of Quaternary deposits in the Sellafield district, west Cumbria. Proceedings of the Yorkshire Geological Society 53, 129-154.

Merritt, J. W., Auton, C. A., Connell, E. R., Hall, A. M., and Peacock, J.D. 2003. The Cainozoic geology and landscape evolution of north-east Scotland. Memoir of the British Geological Survey for the drift editions of 1:50,000 geological sheets 66E, 67, 76E, 77, 86E, 87W, 87E, 95, 96W, 96E and 97 (Scotland).

Mitchell, G. F., Penny, L. F., Shotton, F. W., and West, R. G. 1973. A correlation of Quaternary deposits in the British Isles. Geological Society, London. Special Report 4.

North American Commission on Stratigraphic Nomenclature. 1983. North American stratigraphic code. American Association of Petroleum Geologists Bulletin 67, 841-875.

North American Commission on Stratigraphic Nomenclature. 2005. North American stratigraphic code. American Association of Petroleum Geologists Bulletin 89, 1547-1591.

Räsänen, M. E., Auri, J. M., Huitti, J. V., Klap, A. K. and Virtasalo, J. J. 2009. A shift from lithostratigraphic to allostratigraphic classification of Quaternary glacial deposits. GSA Today 19, 4-11.

Rawson, P. F., and 16 others. 2002. Stratigraphical procedure. Geological Society Professional Handbook. The Geological Society, London.

Reid, C. 1890. The Pliocene deposits of Britain. Memoir of the Geological Survey.

Rose, J. 1994. Major river systems of central and southern Britain during the Early and Middle Pleistocene. Terra Nova 6, 435-443.

Rose, J. 2003. The Quaternary geology of Great Britain - an event stratigraphy based on earth surface dynamics, forced by major climate episodes of the Late Cenozoic. In: Major 
Climate Transitions in the Late Cenozoic (Commission on Glaciation). Abstracts of the 16th International Quaternary Association Congress, Reno, USA, 188.

Rose, J. 2010. The Quaternary of the British Isles: factors forcing environmental change. Journal of Quaternary Science 25, 399-418.

Rose J., Candy, I., Moorlock, B. S. P., Wilkins, H., Lee, J. A., Hamblin, R. J. O., Lee, J. R., Riding, J. B. and Morigi, A. N. 2002. Early and Middle Pleistocene river, coastal and neotectonic processes, southeast Norfolk, England. Proceedings of the Geologists’ Association 113, 47-67.

Salvador, A. 1994. International Stratigraphic Guide. A guide to stratigraphic classification, terminology, and procedure. 2nd Edition. The International Union of Geological Sciences and The Geological Society of America, Colorado, pp. 214.

Schenck, H. G., and Muller, S. W. 1941. Stratigraphic terminology. Bulletin of the Geological Society of America 52, 1419-1426.

Stoker, M.S., Balsom, P.S., Long, D. and Tappin, D.R. 2011. An overview of the lithostratigraphical framework for the Quaternary deposits on the United Kingdom continental shelf. British Geological Survey Research Report RR/11/03.

Stoker, M. S., McMillan, A. A. and Waters C. N. 2012a (in press) Quaternary Stratigraphical Chart: Northern Britain. British Geological Survey, Nottingham.

Stoker, M. S., McMillan, A. A. and Waters C. N. 2012b (in press). Quaternary Stratigraphical Chart: Southern Britain. British Geological Survey, Nottingham.

Stone, P., Millward, D., Young, B., Merritt, J.W., Clarke, S.M., McCormac, M. and Lawrence, D.J.D. 2010. British Regional Geology: Northern England (Fifth edition). British Geological Survey, Keyworth, Nottingham), 294pp.

Whittaker, A., Cope, J.C.W., Cowie, J.W., Gibbons, W., Hailwood, E.A., House, M.R., Jenkins, D.G., Rawson, P.F., Rushton, A.W.A., Smith, D.G., Thomas, A.T. and Wimbledon, W.A. 1991. A guide to stratigraphical procedure. Journal of the Geological Society, London, 148, 813-824.

Willman, H.B., Frye, J.C. 1970. Pleistocene stratigraphy of Illinois. Illinois State Geological Survey Bulletin, No. 94.

Wright, W.B. 1937. The Quaternary Ice Age, 2nd edition. Macmillan, London, 478 pp. 
$\mathrm{N}: \backslash 1$ WORK\SDAG LEX \Lithostrat\PGAlithostratSubmission

\section{Figures}

1. Generalised relationship of the seven groups belonging to the Great Britain Superficial Deposits Supergroup. Bedrock groups and formations of Palaeogene age are also shown (after McMillan et al., 2011).

2. Surface distribution of glacigenic groups and subgroups, the Crag Group and the courses of the ancestral Thames and Bytham rivers (after McMillan et al., 2011).

3. Distribution of catchment subgroups of the Britannia Catchments Group (after McMillan et al., 2011).

4. Profile map of the five subgroups of the Caledonia Glacigenic Group mapped in north-east Scotland, showing generalised flow-lines of ice during the main Late Devensian Glaciation (after Merritt et al., 2003).

5. Distribution of surficial till formations and members of the Caledonia Glacigenic Group (after McMillan et al., 2011).

6. Relationships of formations and subgroups within the Caledonia and Albion subgroups in north-east Scotland (after McMillan et al., 2005). Inset map is a summary of Figure 4.

7. Till formation and member boundaries of Figure 5 draped over the DiGMapGB-625 Bedrock map for Cumbria. Generalised ice flow lines are after Stone et al., 2010, fig. 68). See Figure 5 for key to numbered polygons. Permian and Triassic rocks in the Vale of Eden are in shades of orange and pinkish brown; the Carboniferous Limestone Supergroup in pale blue. For full key to bedrock see free BGS download at http://www.bgs.ac.uk/products/digitalmaps/digmapgb_625.html.

8. NEXTMap hill-shaded digital elevation model of the area around Grantown-on-Spey, showing the boundary between the Central Grampian and East Grampian glacigenic subgroups. Ice sourced in the western Grampian Highlands ice flowed northwards across the Spey - Moray Firth catchment divide creating streamlined landforms and depositing widespread till, whereas sluggish ice centred over the East Grampians caused minimal glacial modification of the landscape.

9. Schematic transect across the Thames Valley near Beaconsfield, showing subgroups and formations within the Britannia Catchments Group and Residual Deposits Group (after McMillan et al., 2011).

Tables 
$\mathrm{N}: \backslash 1$ WORK\SDAG LEX \Lithostrat\PGAlithostratSubmission

1. Summary of the genesis, lithology, distribution and age of the seven groups within the Great Britain Superficial Deposits Supergroup. 
Table 1. Summary of the genesis, lithology, distribution and age of the seven groups within the Great Britain Superficial Deposits Supergroup.

\begin{tabular}{|c|c|c|c|c|}
\hline Group name & Genesis & Lithologies and textures & Distribution & Age \\
\hline $\begin{array}{l}\text { Britannia } \\
\text { Catchments } \\
\text { Group }\end{array}$ & $\begin{array}{l}\text { Fluvial, } \\
\text { organic and } \\
\text { mass } \\
\text { movement }\end{array}$ & $\begin{array}{l}\text { Clastic deposits: boulder, } \\
\text { gravel, sand, silt and clay } \\
\text { grades; periglacial slope } \\
\text { deposits/gelifluctate/ } \\
\text { 'head' }\end{array}$ & Great Britain & $\begin{array}{l}\text { Holocene to pre- } \\
\text { Anglian, MIS 1- } \\
\text { pre-12 }\end{array}$ \\
\hline $\begin{array}{l}\text { Caledonia } \\
\text { Glacigenic } \\
\text { Group }\end{array}$ & Glacigenic & $\begin{array}{l}\text { Clastic deposits; boulder, } \\
\text { gravel, sand, silt and clay } \\
\text { grades; diamictons } \\
\text { (including till) }\end{array}$ & $\begin{array}{l}\text { Great Britain, north } \\
\text { of the Devensian } \\
\text { (Weichselian) ice- } \\
\text { sheet limit }\end{array}$ & $\begin{array}{l}\text { Devensian } \\
\text { (Weichselian), } \\
\text { MIS 2-5d }\end{array}$ \\
\hline $\begin{array}{l}\text { Albion } \\
\text { Glacigenic } \\
\text { Group }\end{array}$ & Glacigenic & $\begin{array}{l}\text { Clastic deposits; boulder, } \\
\text { gravel, sand, silt and clay } \\
\text { grades; diamictons } \\
\text { (including till) }\end{array}$ & $\begin{array}{l}\text { Great Britain, north } \\
\text { of the Anglian ice- } \\
\text { sheet limit }\end{array}$ & $\begin{array}{l}\text { pre-Devensian } \\
\text { (pre- } \\
\text { Weichselian), pre } \\
\text { MIS 5e }\end{array}$ \\
\hline $\begin{array}{l}\text { Residual } \\
\text { Deposits } \\
\text { Group }\end{array}$ & $\begin{array}{l}\text { Residual and } \\
\text { weathering } \\
\text { products }\end{array}$ & $\begin{array}{l}\text { Clastic deposits; gravel, } \\
\text { sand, silt and clay grades }\end{array}$ & Great Britain & $\begin{array}{l}\text { Tertiary to Early } \\
\text { Pleistocene }\end{array}$ \\
\hline $\begin{array}{l}\text { British } \\
\text { Coastal } \\
\text { Deposits } \\
\text { Group }\end{array}$ & $\begin{array}{l}\text { Marine and } \\
\text { coastal }\end{array}$ & $\begin{array}{l}\text { Clastic deposits; gravel, } \\
\text { sand, silt and clay grades }\end{array}$ & $\begin{array}{l}\text { Great Britain, } \\
\text { coastal fringe }\end{array}$ & $\begin{array}{l}\text { Holocene to pre- } \\
\text { Anglian, MIS 1- } \\
\text { pre-12 }\end{array}$ \\
\hline $\begin{array}{l}\text { Dunwich } \\
\text { Group }\end{array}$ & Fluvial & $\begin{array}{l}\text { Clastic deposits; gravel, } \\
\text { sand, silt and clay grades }\end{array}$ & Eastern England & $\begin{array}{l}\text { early Middle to } \\
\text { Early Pleistocene }\end{array}$ \\
\hline Crag Group & $\begin{array}{l}\text { Shallow } \\
\text { marine }\end{array}$ & $\begin{array}{l}\text { Clastic deposits; gravel, } \\
\text { sand, silt and clay grades }\end{array}$ & $\begin{array}{l}\text { Eastern England, } \\
\text { extending offshore }\end{array}$ & $\begin{array}{l}\text { Pliocene and } \\
\text { Early Pleistocene }\end{array}$ \\
\hline
\end{tabular}




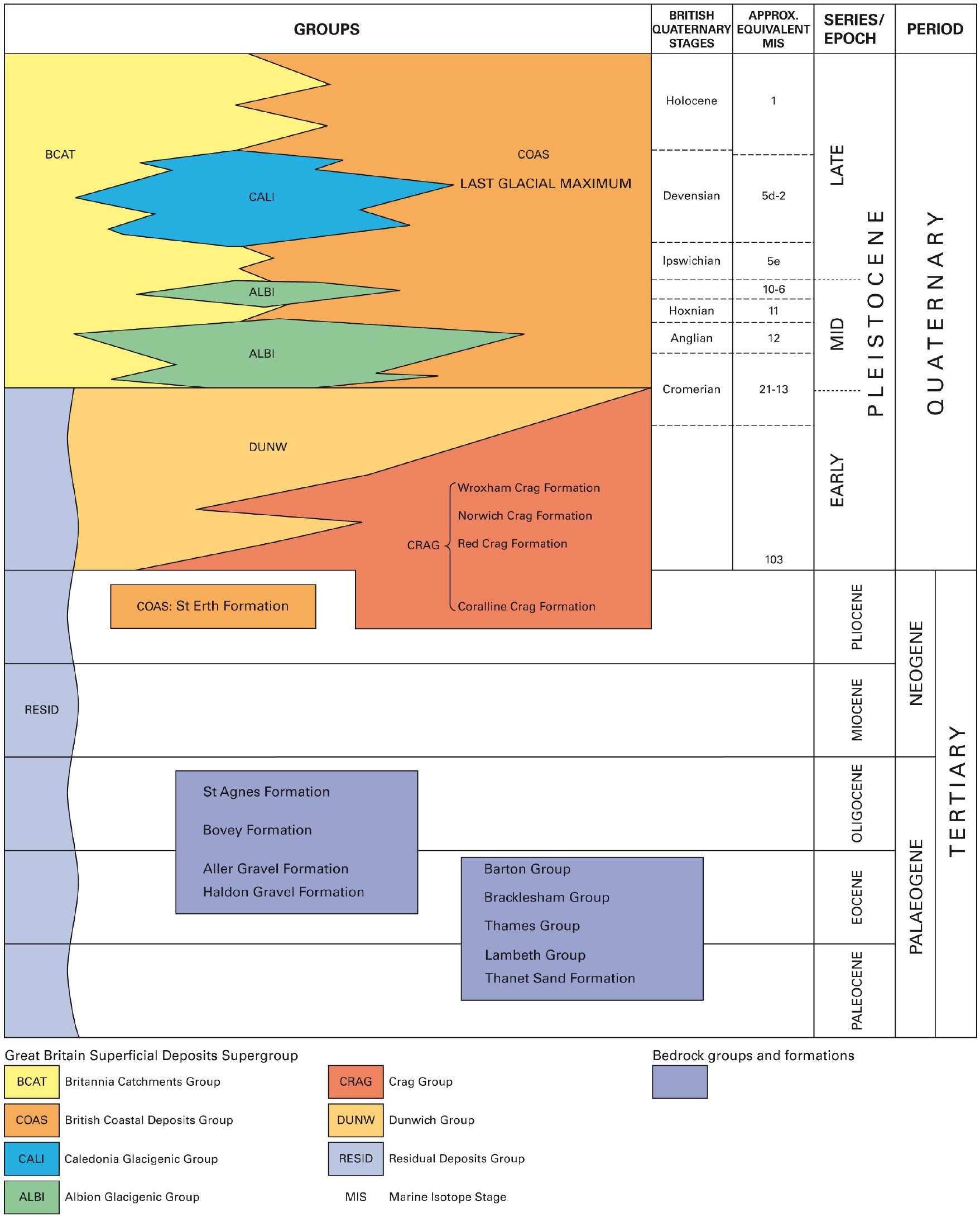


Glacigenic Subgroups of the Caledonia Glacigenic Group

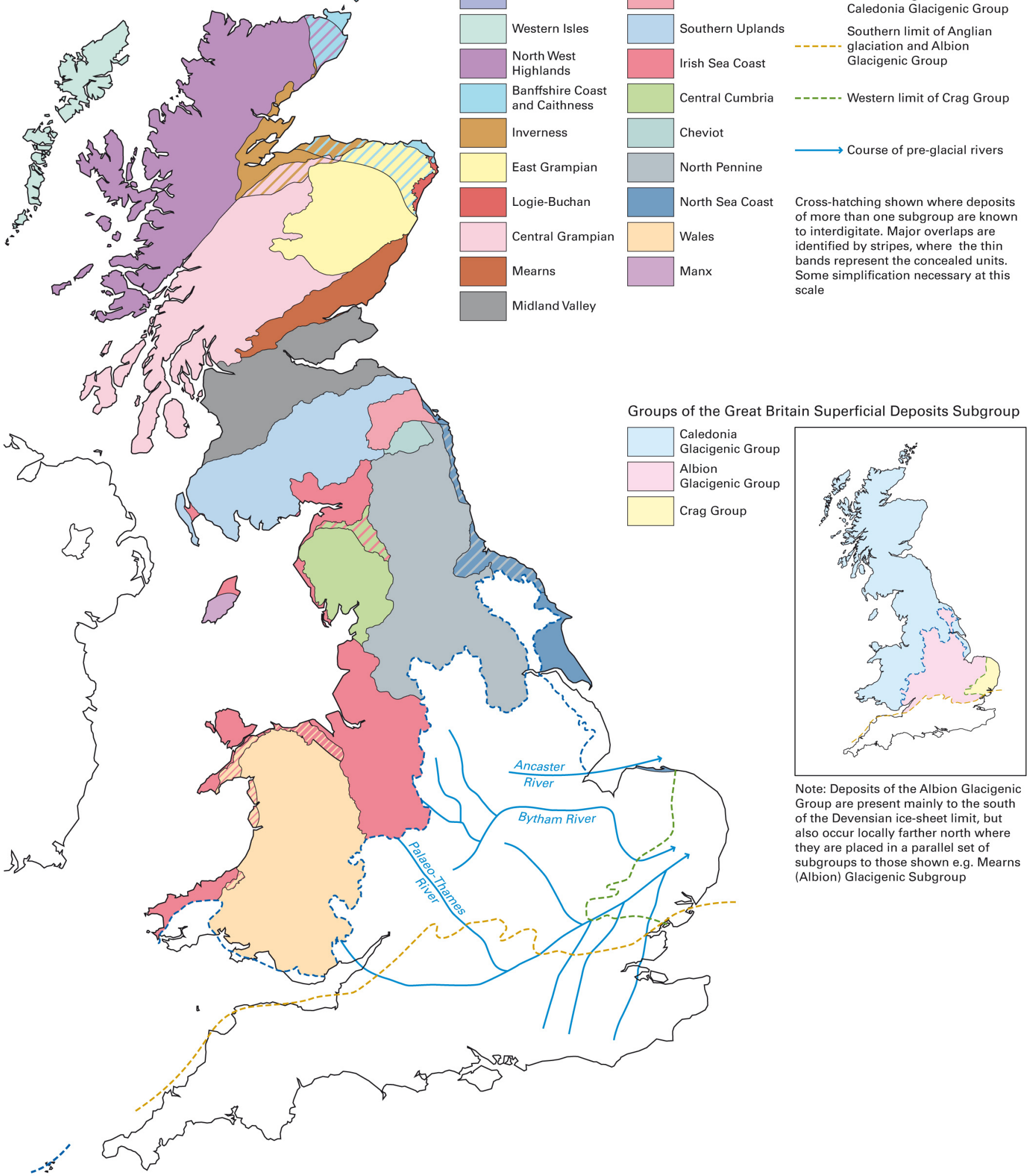





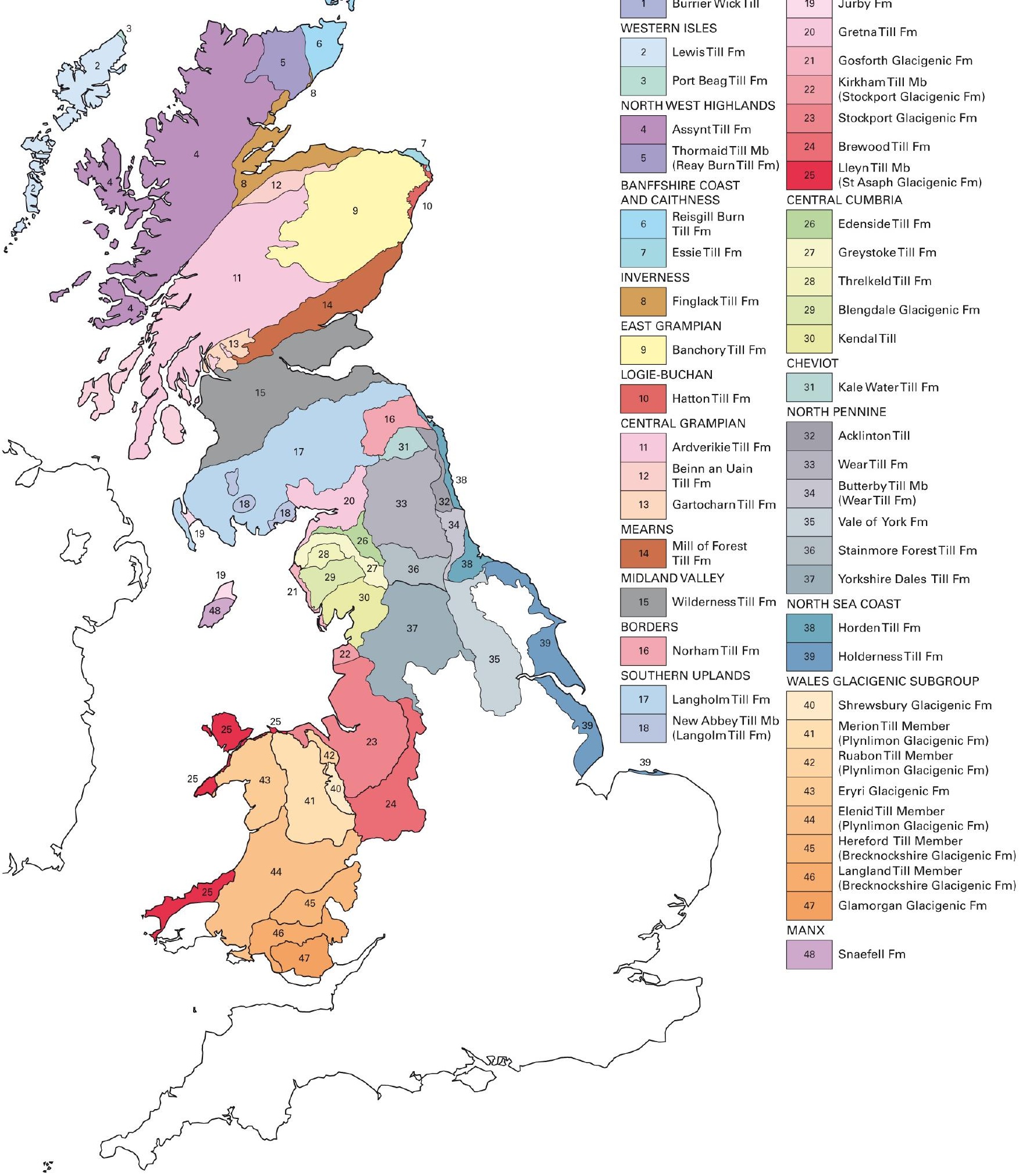




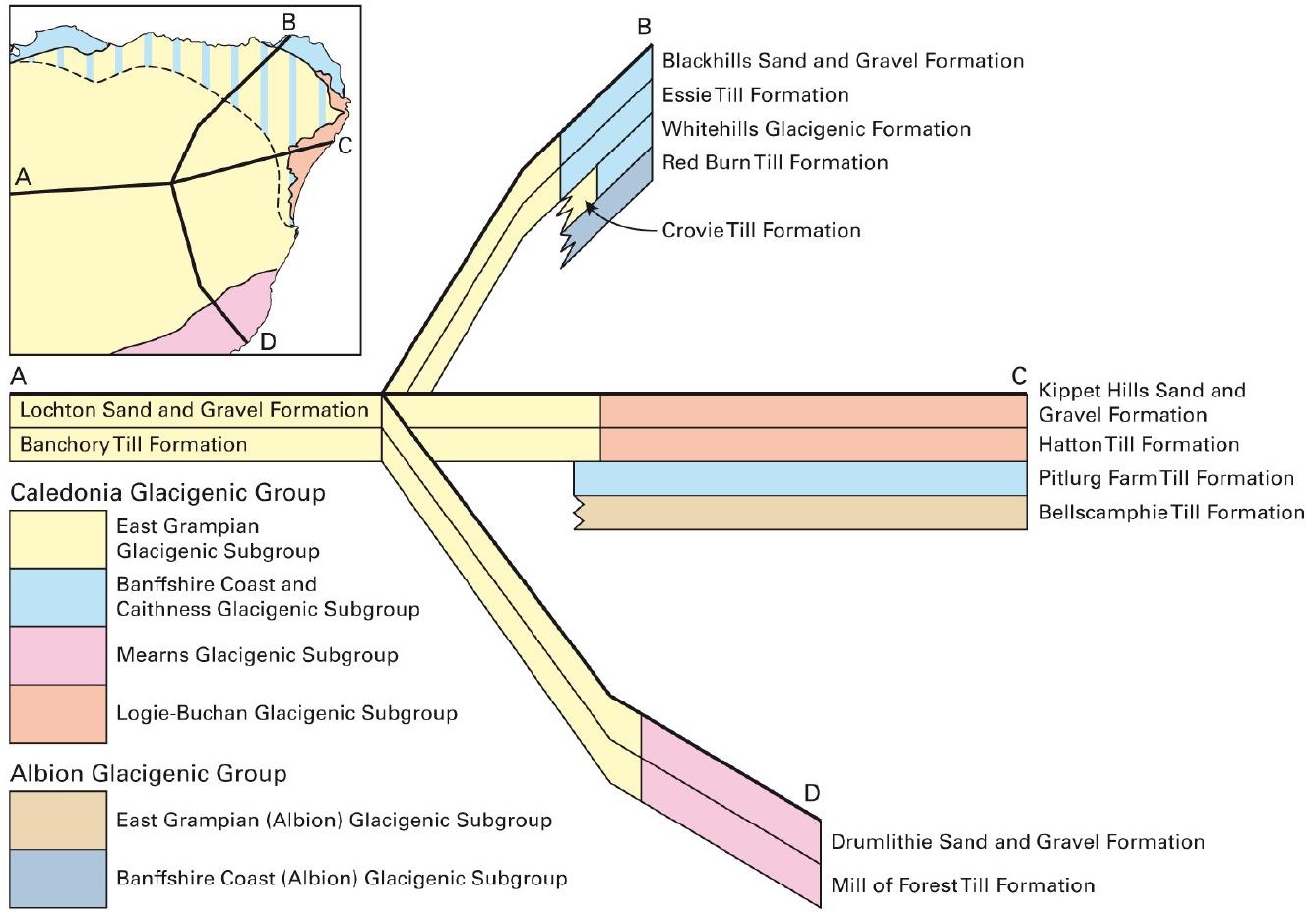





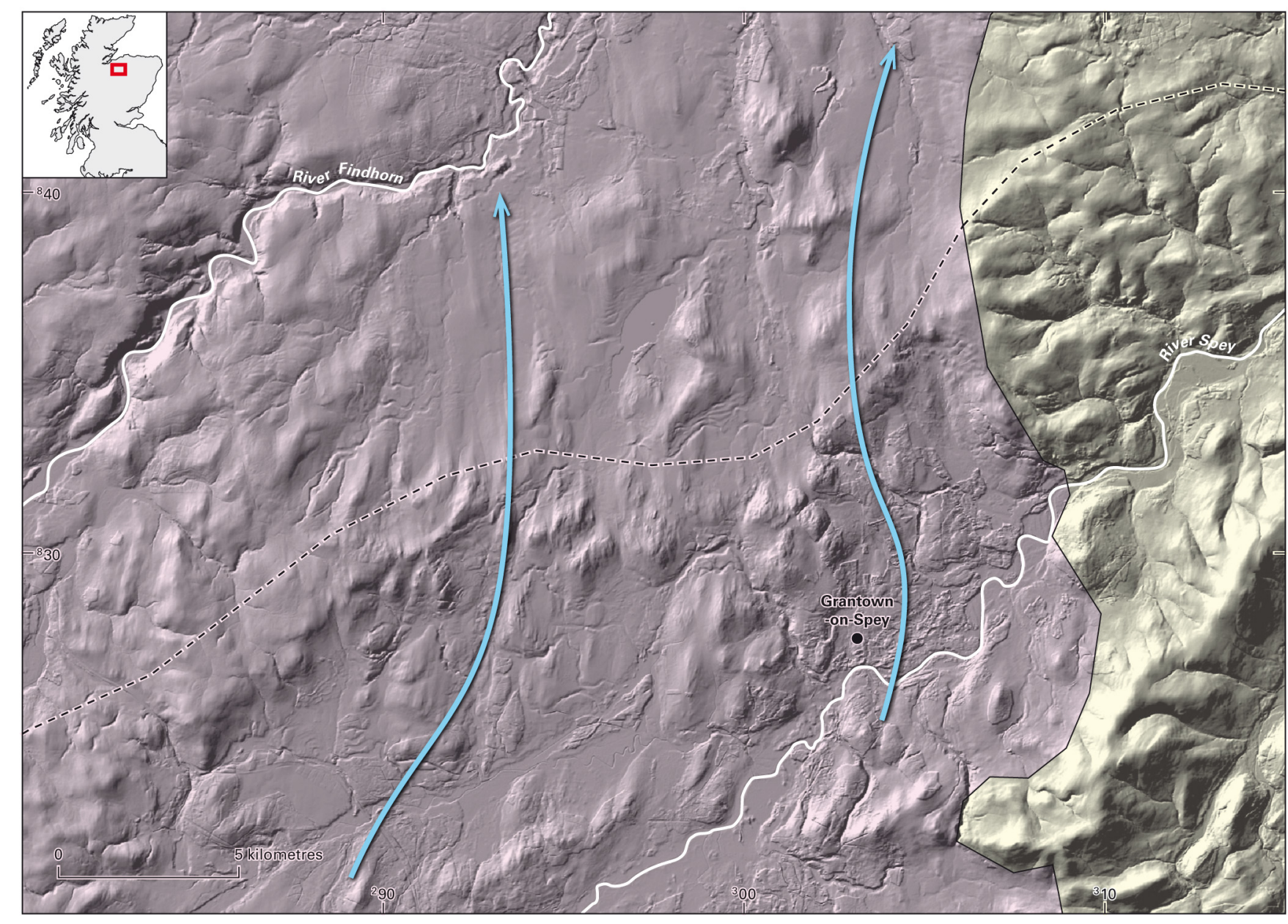




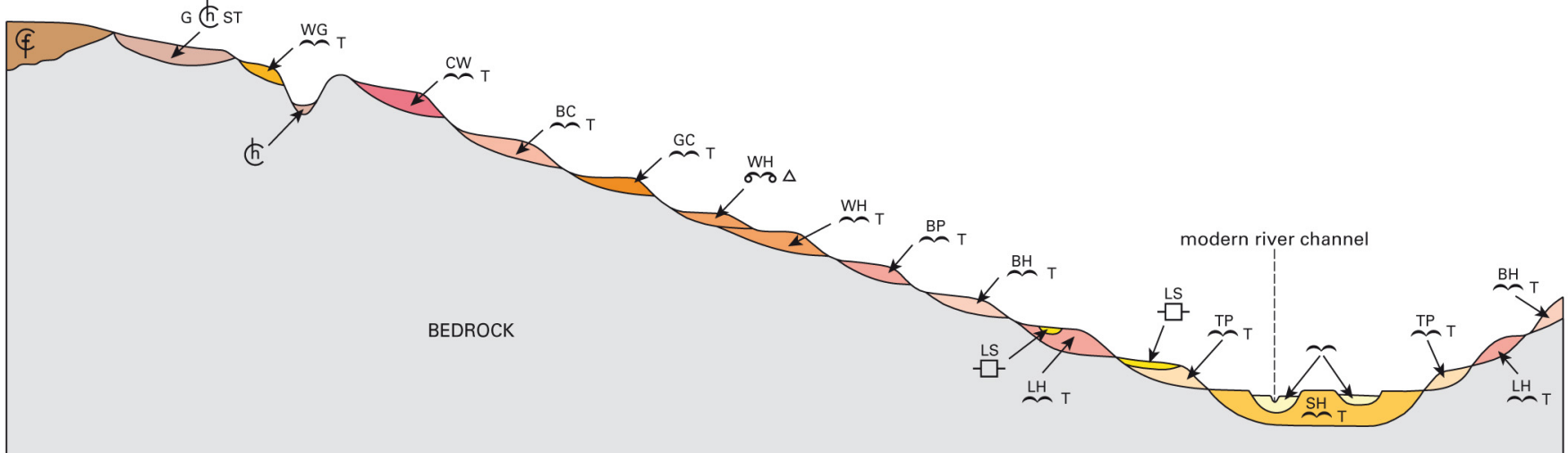

Thames Catchments Subgroup

Maidenhead Formation

\begin{tabular}{|c|c|c|c|}
\hline \multirow{2}{*}{$m$} & \multirow{2}{*}{ Alluvium: mainly silt and clay } & \multicolumn{2}{|c|}{$\begin{array}{l}\text { Sudbury Formation } \\
\text { Suls subgroup }\end{array}$} \\
\hline & & \multirow{2}{*}{ WH } & \multirow{2}{*}{$\begin{array}{l}\text { Winter Hill Gravel Member: } \\
\text { lacustrine delta }\end{array}$} \\
\hline SH & Shepperton Gravel Member & & \\
\hline & & $\stackrel{W H}{T}^{T}$ & \multirow[t]{2}{*}{ Winter Hill Gravel Member } \\
\hline 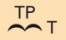 & Taplow Gravel Member & \multirow{2}{*}{$\stackrel{\mathrm{GC}}{T}^{\mathrm{G}}$} & \\
\hline & & & Gerrards Cross Gravel Member \\
\hline$\stackrel{\text { LH }}{\sim}$ & Lynch Hill Gravel Member & \multirow{2}{*}{$\stackrel{B C}{T}_{T}$} & \multirow{2}{*}{ Beaconsfield Gravel Member } \\
\hline $\mathrm{BH}$ & & & \\
\hline$\sim_{T}^{\top}$ & Doym nill G aver Ivientine? & $\mathrm{CW}_{T}$ & \multirow[t]{2}{*}{ Chorleywood Gravel Member } \\
\hline$\stackrel{B P}{\sim} T$ & Black Park Gravel Member & & \\
\hline & & $\stackrel{W G}{T}^{W}$ & \multirow[t]{2}{*}{ Westland Green Gravel Member } \\
\hline$\stackrel{\text { LS }}{\square}$ & Langley Silt Member: sandy clay and silt & & \\
\hline
\end{tabular}

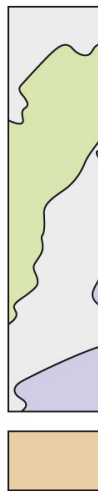

r $105 \%$
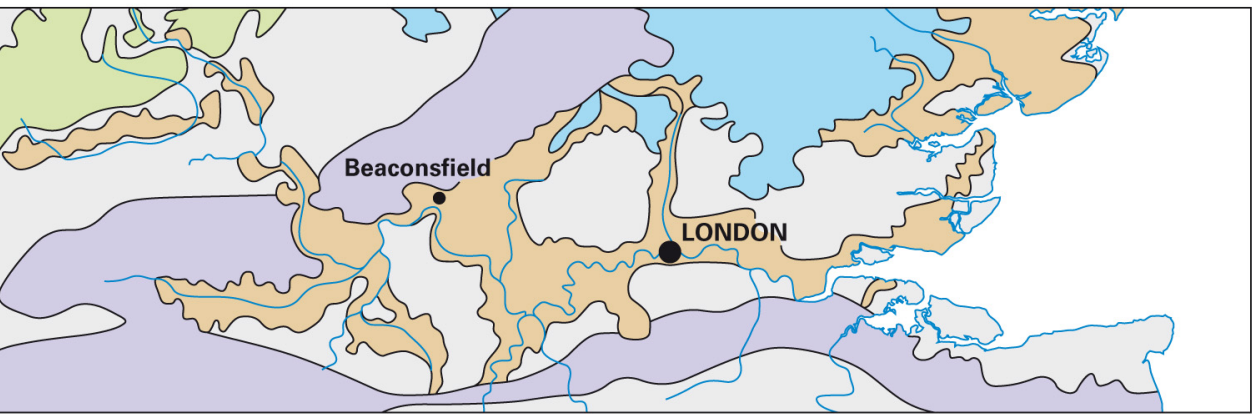

Pleistocene deposits of the Thames system

\section{Dunwich Group}

Sudbury Formation

WH $\quad$ Winter Hill Gravel Member

$\stackrel{\text { GC }}{\mathrm{T}} \quad$ Gerrards Cross Gravel Member

${ }_{\mathrm{BC}}^{\mathrm{B}}$ Beaconsfield Gravel Member

$\stackrel{\mathrm{CW}}{\mathrm{T}}$ Chorleywood Gravel Member

$\stackrel{\text { WG }}{\sim}$ Westland Green Gravel Member
Kesgrave Catchments Subgroup
Chalk outcrop
Jurassic escarpment

\section{Britannia Catchments Group}

\begin{tabular}{|c|c|}
\hline h & Head: stony clay, silt and sand \\
\hline G & $\begin{array}{l}\text { Head gravel: clayey, pebbly, gravel and sand. } \\
\text { Suffix ST indicates sheet-like deposits on plateaux }\end{array}$ \\
\hline
\end{tabular}

\section{Residual Deposits Group}

Clay-with-Flints Formation

f Clay-with-flints: stiff, reddish brown clay with flint nodules; sandy in part

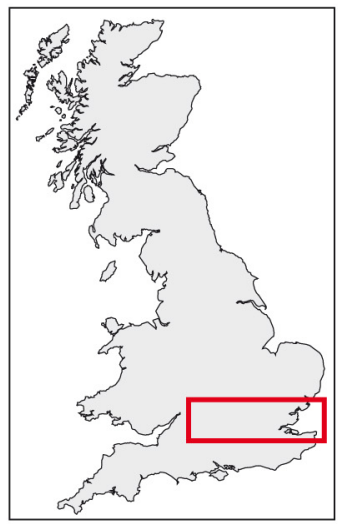

